\title{
Sequential Radical Addition/Cyclization/ß-Elimination Reactions. 3-exo- and 5-exo-Cycloaddition Reactions of 5-Phenylthio-3-pentenyl and 5-Phenylthio-3-pentynyl Radicals
}

\author{
Radomir N. Saicič and Živorad Čekovic \\ Department of Chemistry, Faculty of Sciences, University of Belgrade, Studentski trg 16, P.O. Box 550, 11001 Belgrade and \\ IHTM Institute for Organic Chemistry and Biochemistry, Belgrade, Yugoslavia
}

(Received in UK 31 July 1992)

Key Words: sequential radical reactions; $3+2$ cycloadditions; 5 -phenylthio-3-pentenyl radicals, thiohydroxamic esters of 6-phenylthio-4-hexenoic acids.

\begin{abstract}
Sequential radical addition/5-exo-cyclization/B-elimination reactions, accomplished by thermally or photolytically induced decompositions of $\mathrm{O}$-acyl derivatives of $\mathrm{N}$-hydroxypyridine-2-thione or other thiohydroxamic esters of 6-phenylthio-4-hexenoic acids 11 in the presence of an excess of radicophilic olefins, afforded the 2vinylcyclopentane derivatives 13 in 50-90\% yields, while decompositions of thiohydroxamic esters or 6-phenylthio-4-hexynoic acids 24, under the same experimental conditions and in the presence of electron deficient olefins, afforded the corresponding 2-vinylidenecyclopentane (2-exo-allenic cyclopentane) derivatives 25 (61-72\%). However, when decompositions of thiohydroxamic esters 39 were carried out in boiling roluene solution without radicophilic olefins, 3-exo-cyclization took place and the corresponding 2-vinylcyclopropane derivatives 40 were obtained in 43$-60 \%$ yields.
\end{abstract}

Tandem sequence of radical addition/cyclization reaction represents a simple and very useful methodology for annulation of polysubstituted cyclopentane rings. ${ }^{1-3}$ Starting from two appropriate unsaturated synthons 1 and 2 , by this sequence of reactions, $3+2$ cycloaddition takes place involving two carbon-carbon bonds formations. ${ }^{1,4,5}$ In addition to the tandem sequences ${ }^{4,6-16}$ higher sequential radical transformations were
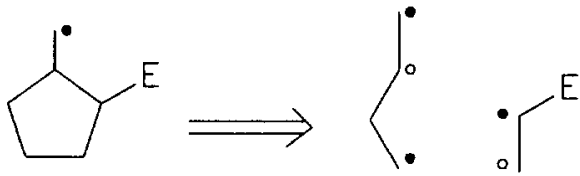

1

Scheme 1.

systematically investigated by designing the appropriate substrates, selection of reaction conditions and reagents, and following sequences such as addition/cyclization/addition, ${ }^{1,2}$ addition/cyclization/atom transfer $^{17}$ and fragmentation/addition/cyclization ${ }^{18}$ were successfully applied in the synthesis of complex polycyclic compounds. 16

In all of these sequential radical reactions several radical intermediates were involved in the propagation step of these radical chain reactions. The reactivities of the intermediary radicals involved in the key sequence, e.g. addition/cyclization, have to be in accordance with the reactivity of the corresponding unsaturated bonds, ${ }^{19}$ 
and follows the rule: nucleophilic radicals readily react with the electron deficient alkenes, while electrophilic radicals rapidly undergo addition to the electron rich alkenes. ${ }^{4,19,20}$ In order to achieve successful sequential reaction, all of the reactions involved in the key sequence must be faster than the reactions which could terminate the chain reaction.

Herein, we investigated the sequence of reactions involving an addition/cyclization/ $/$-elimination and its application to the construction of polysubstituted cyclopentane ring. In order to realize this sequence of reactions it was necessary to design appropriate substrates for generation of radical intermediates possessing a reactivity which corresponds to the expected reactivity of intermediary species, having in mind that addition of nucleophilic radicals to electron deficient olefinic bonds $\left(K_{\mathrm{a}}=3 \times 10^{5} \mathrm{sec}^{-1}\right)^{20}$ and 5-exo-cyclization of electrophilic radicals $\left(K_{c}=1 \times 10^{6} \mathrm{sec}^{-1}\right)^{21}$ proceeds smoothly. When tributyltin hydride method is applied and cyclopentylmethyl radical has electrophilic character, termination reaction involves abstraction of hydrogen $\left(\mathrm{K}_{\mathrm{H}}=2 \times 10^{6} \mathrm{sec}^{-1}\right)^{22}$, however, when cyclopentylmethyl radical has nucleophilic properties the addition to the electron deficient olefinic bonds takes place. ${ }^{1,2}$ We assumed that the cyclopentylmethyl radical 3 , generated by $3+2$ cycloaddition, could undergo the elimination reaction, as the termination step, if it possesses a good radical leaving group in the B-position. By inspection of rates of involved reactions we found that Barton method ${ }^{23}$ of generation of starting alkenyl radical 4 (Scheme 2.) from the corresponding
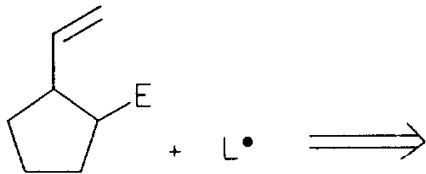

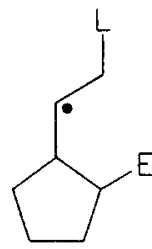

3

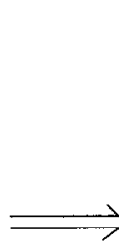

4
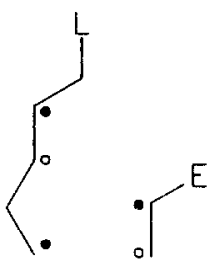

2

Scheme 2.

thiohydroxamic esters, could be a method of choice. In order to discipline the cyclopentylmethyl radical 3 to only one manner of stabilization in a termination step, it was necessary to introduce a phenylthio or tributylstannyl groups into the $B$-position in respect to radical center 3 , i.e. in the position 5 of the initial alkenyl radical 4 , because the rate of $B$-elimination of these groups $\left(K_{e}=1.6 \times 10^{7} \mathrm{sec}^{-1}\right)^{24}$ is higher than addition of cyclopentylmethyl radical onto the starting electron deficient olefinic compounds 1 . This methodology could have synthetic value if the eliminated radical $L \cdot$ reacts with a radical precursor to propagate a chain (the rate of addition of alkyl radical to $\mathrm{C}=\mathrm{S}$ group of thiohydroxamic ester is $\mathrm{K}=1.3 \mathrm{x} 10^{6} \mathrm{sec}^{-1}$ ). ${ }^{25}$

We assumed that the sequence of addition(i)/cyclization(ii)/elimination(iii) reactions and construction of functionalized vinylcyclopentane derivatives 5 could be realized if thiohydroxamic esters of 6-phenylthio-4-hexenoic acids were used as precursors of 5-phenylthio-3-pentenyl radical 4 (Scheme 3.). ${ }^{26}$ Since 5phenylthio-4-pentenyl radical 4 is relatively nucleophilic with high-lying SOMO it was necessary to use as radical acceptors compounds possessing a low-lying LUMO of olefinic bond, such as compounds having an electron-withdrawing group attached on the olefinic carbon atom. ${ }^{4,19}$

Synthesis of thiohydroxamic esters of 6-phenylthio-4-hexenoic acids 11 were realized according to Scheme 4. Preparation of 2-alkylated 6-phenylthio-4-hexenoic acids 9 were carried out by alkylation of esters 


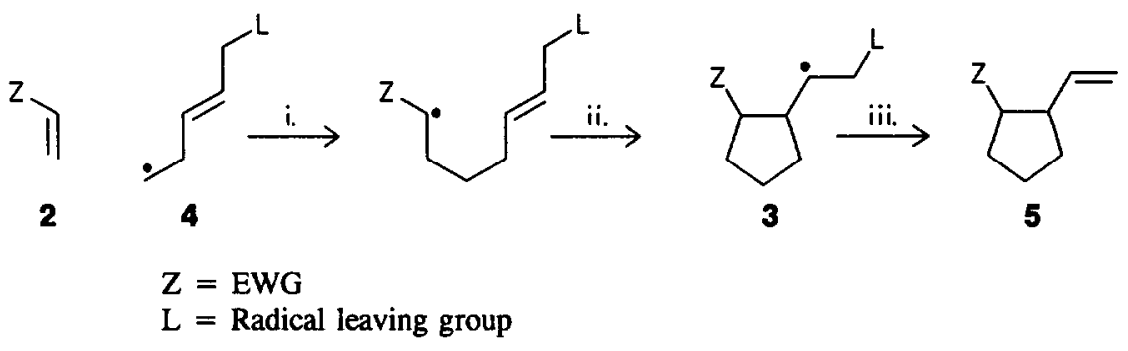

Scheme 3.

6 by (E)-1,4-dibromo-2-butene using LDA as a base. By substitution of bromine with thiophenyl group and by hydrolysis of ester 8 (see Experimental) 2-alkylated 6-phenylthio-4-hexenoic acids 9 were prepared.

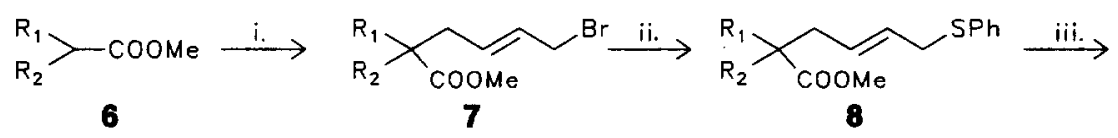<smiles>[R2]C([R2])(C)C/C=C/CSc1ccccc1</smiles>

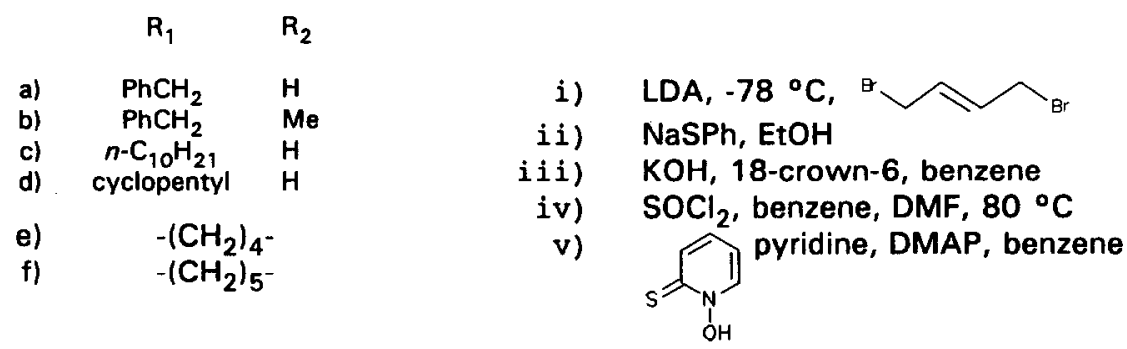

Scheme 4.

Thiohydroxamic esters 11 (Scheme 4.) were prepared in good yields according to the Barton's procedures, ${ }^{23,27}$ by addition of 6-phenylthio-4-hexenoic acid chlorides 10 to the equal amount of $\mathrm{N}$ -hydroxypyridine-2-thione or 3-hydroxy-4-methylthiazole-2 $(3 \mathrm{H})$-thione, pyridine and 4-dimethylaminopyridine (DMAP) in benzene solution. Thiohydroxamic esters 11 prepared in benzene solution were decomposed in the presence of 3-5 molar excess of electron deficient olefins 12 by irradiation with a sunlamp $(200 \mathrm{~W})$ during 1 h. However, when decomposition of thiohydroxamic esters were carried out under thermal conditions starting esters were prepared in ether solution, and after removal of solvent the ester was dissolved in toluene and then 
was slowly added to the boiling solution of excess of radicophilic olefins and catalytic amount of AIBN in toluene. Decomposition was carried out at reflux temperature and reactions were completed during 15 min. ${ }^{26}$

Under these experimental conditions thiohydroxamic esters 11 were converted into the 2-vinylcyclopentane derivatives 13 and 2-pyridylphenyl disulfide 14 as final reaction products, and they were separated by chromatography on silica gel column. The reaction products and their yields are presented in the Scheme 5 .

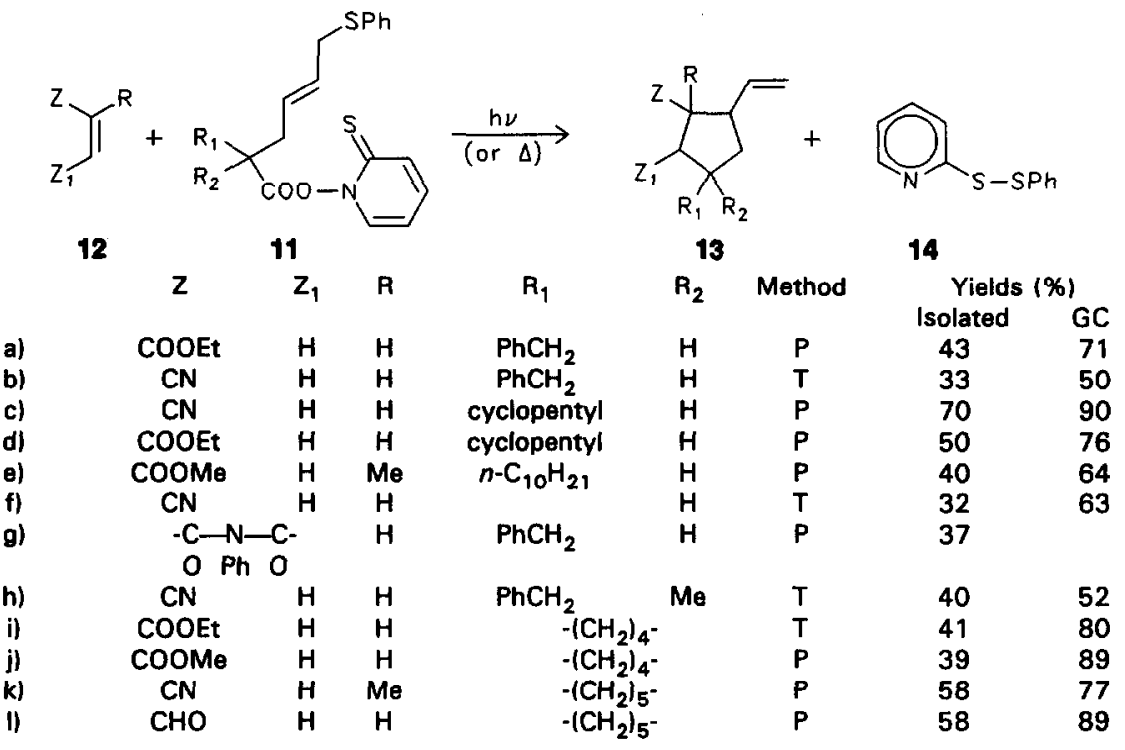

P - Photolytically induced decomposition

$T$ - Thermal decomposition

Scheme 5 .

Sequential addition/cyclization/ß-elimination reactions took place when decompositions of thiohydroxamic esters 11 were performed under photolytic (11a, c, d, e, g, j, k, l) and thermal (11b, f, h, i) conditions, however lower yields (50-63\%) of 2-vinylcyclopentane derivatives 13 were obtained when reactions were performed by thermal decomposition of starting esters, than when thiohydroxamic esters were irradiated, when higher yields $(64-90 \%)$ of annulation products were obtained.

The sequence of radical chain reactions involving an addition/cyclization/B-elimination is initiated by decomposition of $\mathrm{N}$-hydroxypyridine-2-thione esters of $\alpha$-substituted 6-phenylthio-3-hexenoic acids. Reaction was induced by addition of phenylthio radical to the $\mathrm{C}=\mathrm{S}$ bond of starting ester which proceeds with a concerted or stepwise homopolar cleavage of $\mathrm{N}-\mathrm{O}$ bond thus arising an intermediary carboxy radical 15 and by decarboxylation a 5-phenylthio-3-pentenyl radical 16 was generated (Scheme 6.). Possessing nucleophilic character a homoallyl radical 16, in the following step, preferentially undergoes the regioselective addition to the radicophilic olefins 12 thus generating a radical 17. In order to favour the addition of radical 16 to the electron deficient olefins 3-5 molar excess of olefins 12 were used. With this ratio of starting compounds the addition of homoallyl radical $\mathbf{1 6}$ to olefins was increased, while its addition to the $\mathrm{C}=\mathrm{S}$ bond of starting thiohydroxamic esters 11 was suppressed. 


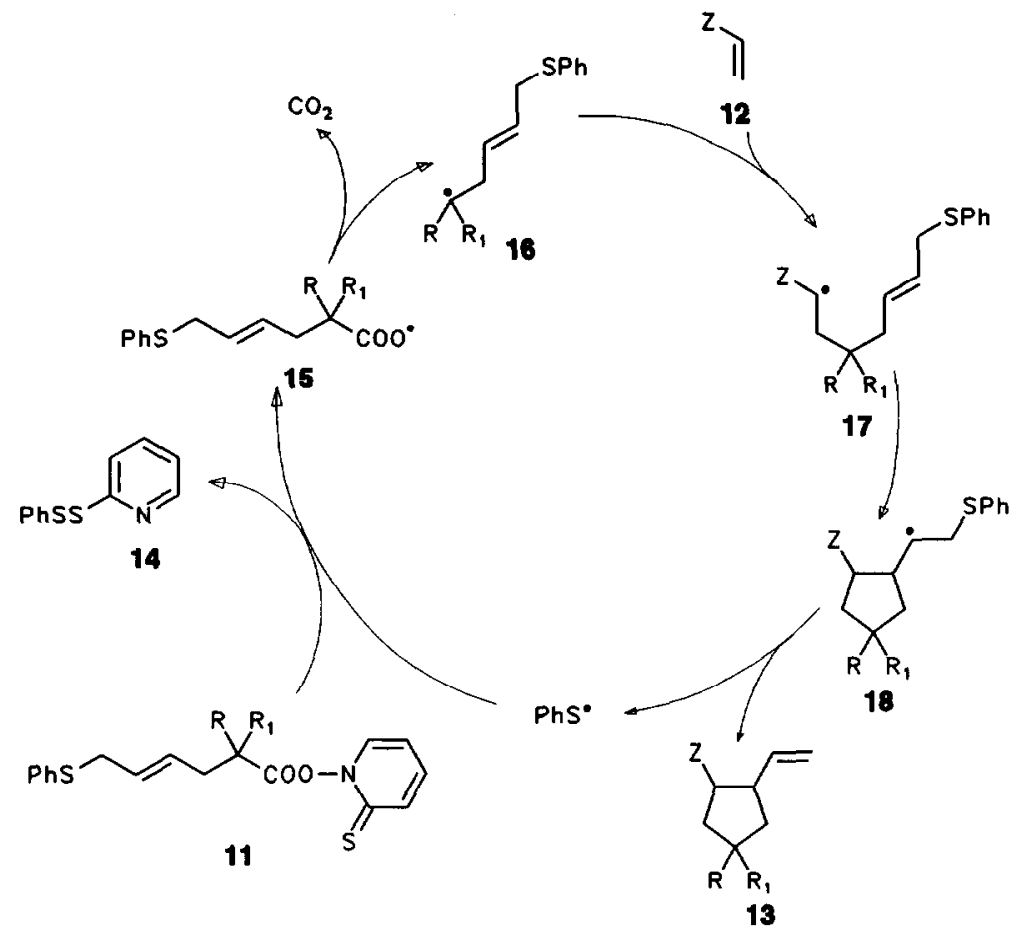

Scheme 6.

Electrophilic radical 17 rather undergoes the 5-exo-cyclization with formation of a cyclopentylmethyl radical 18 (Scheme 6.). Other reactions of radical 17 such as addition to the $\mathrm{C}=\mathrm{S}$ bond of thiohydroxamic esters, or to the electron deficient olefins were not observed.

Although cyclopentylmethyl radicals 18, possessing nucleophilic properties, are similar to the homoallyl radicals 16, they do not undergo the intermolecular addition to the starting olefinic compound as a radicophil, but possessing a phenylthio group as a good leaving group, at the neighboring carbon atom they rather undergo the B-elimination reaction $\left(K_{e}>1.6 \times 10^{7} \sec ^{-1}\right)$ thus affording 2-vinylcyclopentane derivatives 13 as final reaction products and generating a phenylthio radical as a chain carrying radical. By addition of phenylthio radical to the $\mathrm{C}=\mathrm{S}$ bond of starting esters a new propagation step involving addition/cyclization/ $\mathbb{\beta}$-elimination starts.

This sequence of reactions involving two carbon-carbon bond formations and elimination reaction is named addition/cyclization/elimination, although this free radical chain reaction involves several steps, such as addition of $\mathrm{PhS}$ radical to the $\mathrm{C}=\mathrm{S}$ bond, homopolar cleavage of $\mathrm{O}-\mathrm{N}$ bond and decarboxylation of carboxyl radical prior to the formation of 5-phenylthio-3-pentenyl radical 16, which has to be considered as an initiation step in respect to the addition/cyclization/elimination sequence as a propagation step.

Electrophilic 5-phenylthio-3-pentenyl type radical, generated by addition of phenylthio radical to the vinylcyclopropane also undergoes the same sequence of addition/cyclization/elimination reaction, thus affording vinylcyclopentane derivatives in high yields. ${ }^{28}$ However, when 5-tributylstannyl-3-pentenyl radical was 
generated by tributyltin hydride method (catalytic or equal amount of $\mathrm{Bu}_{3} \mathrm{SnH}$ was used) from the corresponding iodide, poor yields of the 2-vinylcyclopentane derivatives were obtained. ${ }^{29}$

By this sequence of radical reactions polysubstituted vinylcyclopentane derivatives 13 were obtained as mixtures of stereoisomers. When acrylonitrile was used as a radicophile and secondary 5-phenylthio-3-pentenyl radical 16 was involved, two stereoisomers were obtained in the ratio of $1: 1$, although three possible isomers exist. However, when esters of acrylic acid were used one stereoisomer predominates. The stereoisomeric vinylcyclopentane derivatives 13 were only detected by gas chromatography, we were not able to separate them, and they were characterized as mixtures of stereoisomers. According to Beckwith's model ${ }^{30}$ for cyclization of primary and secondary 3-substituted hexenyl radicals, and Houk's calculations ${ }^{31}$ we believe that cyclization of 5-heptenyl radical 17 involves 5-exo-chair transition state 19 with equatorial-like substituent in the position 3. Transition state 19 having substituent at radical center (position 1) in equatorial-like position give a 1,5-cis-isomer 20, while a transition state 21 with axial-like position of substituent at the radical center affords a 1,5-trans-isomer 22 (Scheme 7.). By using acrylonitrile as a radicophile, the difference between the

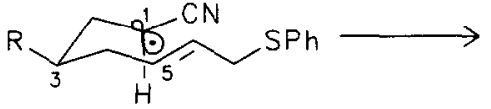

19

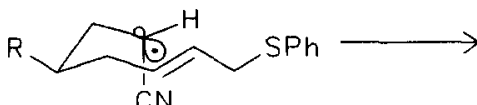

21

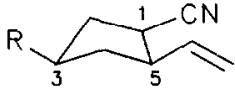

20

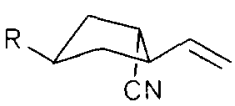

22

Scheme 7.

transition states 19 and 21 is very low, because of linearity of cyano group and 1,5-cis- (20) and 1,5-trans-isomer (22) were obtained in almost equal amounts. When other radicophilic olefins were used the ratio of isomers varied, because of stereochemical requirements in the transition state and usually one isomer predominates.

Recently it was demonstrated that 3-butynyl type radical, generated by tributyltin hydride ${ }^{3}$ or hexabutylditin methods, ${ }^{17}$ undergoes the addition to the radicophilic olefins, thus generating an electron deficient 5-hexenyl type radical. By 5-exo-dig-cyclization reaction this radical affords 2-alkylidenecyclopentane derivatives. ${ }^{4,6}$ We undertook to realize our sequence of reactions, i.e. addition/cyclization/ß-elimination involving a 5-phenylthio-3-pentynyl radical intermediates. Thus by photolytically induced decomposition of thiohydroxamic ester of 6-phenylthio-4-hexynoic acid $24^{32}$ in benzene solution, in the presence of 5-foid molar excess of radicophilic olefins 23, 2-vinylidenecyclopentane derivatives 25 were obtained in 61 to $72 \%$ yields, in addition to the 2-pyridylphenyl disulfide as a side product (Scheme 8.). 


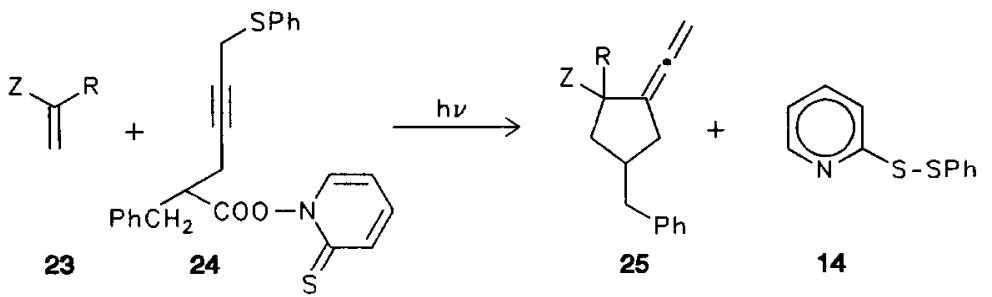

R Z

Yields (\%) Isolated GC
a)
H
$\mathrm{CN}$
32
65
b)
H
COOEt
40
65
c)
$\mathrm{Me}$
$\mathrm{CN}$
41
72

Scheme 8.

This annulation of cyclopentane ring involves the same sequence of reactions and the course of this chain reaction, the rates of generation of 5-phenylthio-3-butynyl radical 26, as well as the rate of its addition to the radicophilic olefins 23 (Scheme 9.) are quite similar to the above described sequence of reactions

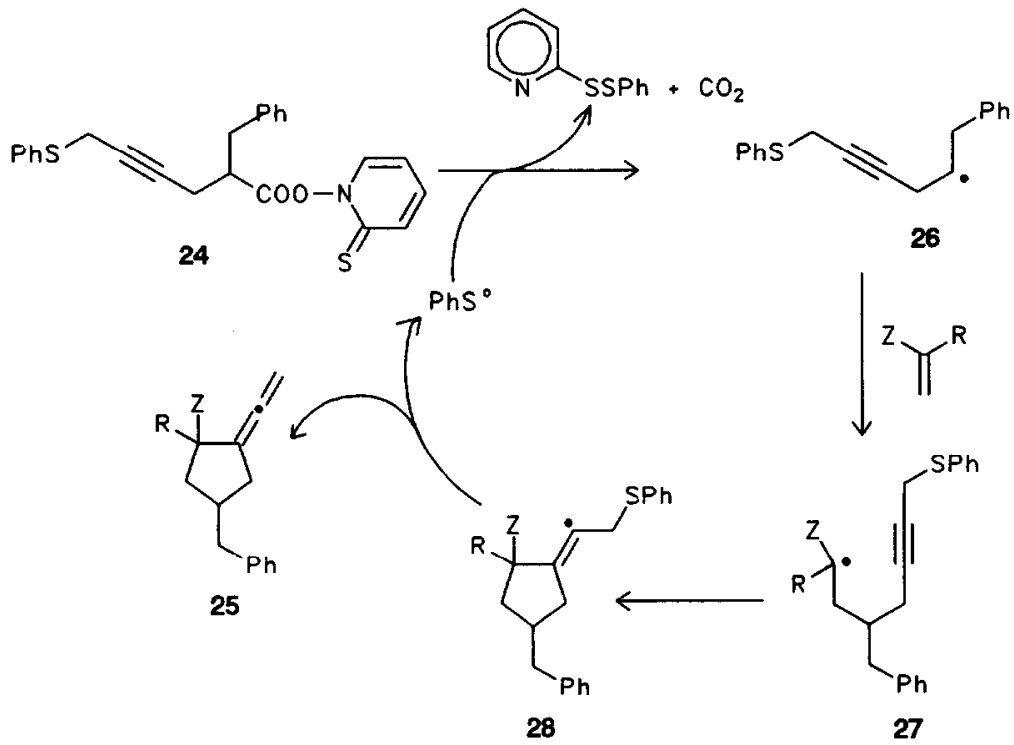

Scheme 9.

affording a vinylcyclopentane derivatives (Scheme 6.). Somewhat lower yields of vinylidenecyclopentane derivatives 25 , in comparison to vinylcyclopentane derivatives, could be explained by lower rate of cyclization of 5-hexynyl type radical $27\left(\mathrm{~K}_{\mathrm{c}}\right.$ 5-exo-dig $\left.=10^{5} \mathrm{sec}^{-1}\right)$ than hexenyl radical and in such conditions the addition of 5-hexynyl type radical 27 to the $\mathrm{C}=\mathrm{S}$ bond of starting thiohydroxamic ester 24 could be a considerable 
competing reaction. We believe that B-elimination of $\mathrm{PhS}$ from the intermediary vinyl radical 28 is a fast reaction, although kinetic parameters for this type of elimination reaction were not yet described.

Free radical annulation of substituted and functionalized cyclopentane derivatives 29-33 from radicophiles 1 and 3-butenyl type radicals 34, involving a cyclopentylmethyl radicals 35, is a useful synthetic methodology for the construction of cyclopentane rings (Scheme 10.). Depending on the methods for the

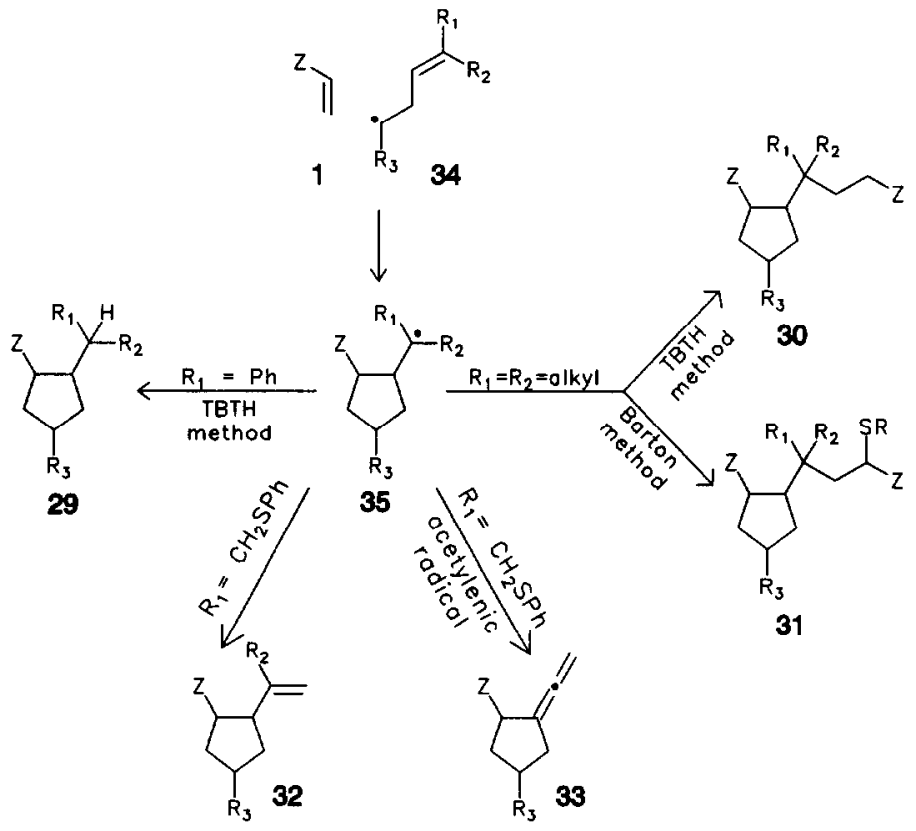

Scheme 10.

generation of 3-butenyl type radical and substituents on the radicophile 1 as well as the precursor of 3-butenyl radical 34 cyclopentane derivatives $29-33$, bearing different substituents and functional groups were prepared.

\section{3-exo-Cyclization of 5-Phenylthio-3-pentenyl Radicals}

The rate of 3-exo-cyclization of 3-butenyl type radical is very low $\left(\mathrm{K}_{\mathrm{c}}\right.$ 3-exo-trig $\left.=0.8-1.3 \times 10^{4} \mathrm{sec}^{-1}\right){ }^{33}$ Due to the ring strain the rate of ring opening of cyclopropylmethyl radical is considerably higher $\left(\mathrm{K}_{\mathrm{f}}=1.3\right.$ $\left.\times 10^{8} \mathrm{sec}^{-1}\right)^{21,34}$ and synthetic utility of this reaction was limited. Because of considerable difference between the rates of cyclization ( $\mathrm{K}_{\mathrm{c}}{ }^{3-e x 0^{-}}$) and fragmentation $\left(\mathrm{K}_{\mathrm{f}}\right)$ the equilibrium is on the side of 3-butenyl type radical, even when stabilizing substituents are present on the radical carbon atom at the cyclopropylmethyl radical. ${ }^{35}$ So, free radical cyclopropane ring formation was rather considered as a 3-butenyl/cyclopropylmethyl radical interconversion than as a method for the construction of a three membered carbocyclic ring. ${ }^{36}$ In several reactions cyclopropylmethyl radicals were observed as intermediates in 1,2-group migration and were usually in equilibrium with 3-butenyl type radicals. ${ }^{12,34,35,37-40}$ Cyclopropane derivatives were only prepared 
by a free radical displacement in 3-butenylcobaloximes by halomethyl radicals ${ }^{41}$ or when stereochemistry of the intermediary radical favours the 3-exo-cyclization. 42,43

We assumed that 3-exo-cyclization of 3-butenyl radicals to cyclopropane derivatives could be achieved by an efficient quenching of the intermediary cyclopropylmethyl radicals. In order to favour 3-exo-cyclization and to suppress reversible opening of the cyclopropylmethyl radical it was necessary to design a radical precursor and to find a reaction for quenching of radicals $\left(\mathrm{K}_{q}\right)$ having a rate constant higher than a ring opening $\left(K_{q}>K_{f}\right)$ (Scheme 11.). Since it was estimated that the rate of elimination of phenylthio group,

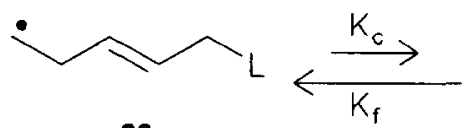

38

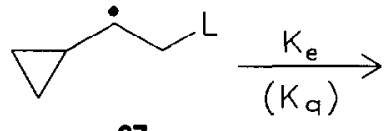

37

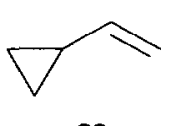

38

Scheme 11 .

adjacent to a radical center would be higher than $\mathrm{K}_{\mathrm{e}}>1.6 \times 10^{7} \mathrm{sec}^{-1}$, we wanted to check if this elimination could be a faster reaction than opening of cyclopropylmethyl radical 37 in boiling toluene and be a good propagation step in the radical chain reaction affording a cyclopropane 38 as a final reaction product (Scheme 11.).

Free radical 3-exo-cyclization with a cyclopropane ring formation was accomplished when 3-pentenyl type radical 36 possessed a phenylthio group, as a good leaving group, in the position 5.44

We assumed that Barton's method for the generation of 3-butenyl radicals was preferred and as a good precursor of radical allowing 3-exo-cyclization we selected thiohydroxamic esters of 6-phenylthio-4-hexenoic acid 39. Thermal decompositions were carried out by dropwise addition of toluene solutions of esters 39 to the refluxing toluene. Under these conditions the corresponding 2-vinylcyclopropane derivatives $\mathbf{4 0}$ were obtained in addition to 4-methyl-2-thiazolylphenyl disulfide 41 (Scheme 12.).

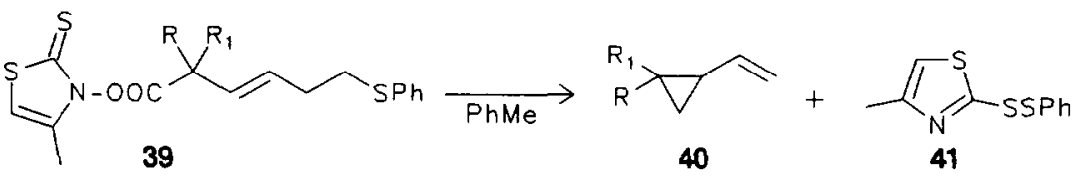

\begin{tabular}{ccccc} 
& $\mathrm{R}$ & $\mathrm{R}_{1}$ & \multicolumn{2}{c}{ Yields (\%) } \\
& & & Isolated & $\mathrm{GC}$ \\
a) & $\mathrm{H}$ & $\mathrm{PhCH}_{2}$ & 32 & 47 \\
b) & $\mathrm{Me}$ & $\mathrm{PhCH}_{2}$ & 25 & 43 \\
c) & $\mathrm{H}$ & $n-\mathrm{C}_{10} \mathrm{H}_{21}$ & 30 & 60
\end{tabular}

Scheme 12 .

The intermediary 5-phenylthio-3-pentenyl radicals 42 generated by decarboxylation of starting thiohydroxamic esters 39, in the absence of radicophilic olefins undergo the intramolecular 3-exo-cyclization thus giving a cyclopropylmethyl radical $\mathbf{4 3}$ (Scheme 13.). We believe that 3-exo-cyclization involves a transition state in which $E$-configuration of olefinic bond of radical $\mathbf{4 2}$ permits the coplanarity of four carbon atoms chain to be perpendicularly oriented to SOMO of homoallyl 42 . Since the distance between carbon radical and attacking olefinic carbon atom for 3 -exo-cyclization is about $2.50 \AA$, which is considerably longer 


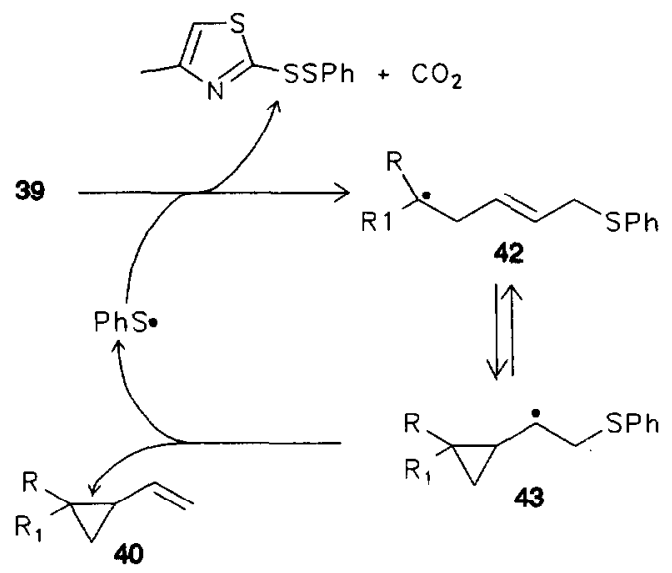

Scheme 13.

than the distance required for 5-exo-cyclization $(2.34 \AA)$ and optimal distance for radical addition reactions $(2.00 \AA)$, some additional activation is required in order 3-exo-cyclization to occur. In this case the activation of olefinic bond was achieved by phenylthio group in the allylic position which lowers a LUMO of olefinic bond and thus favours an interaction with SOMO (Fig. 1.).

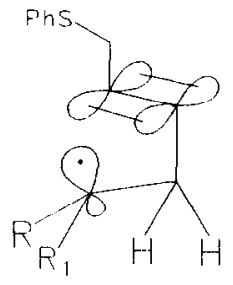

Figure 1.

3-exo-Cyclization in this conformational circumstances proceeds with concomitant expulsion of phenylthio radical without full developing of cyclopropylmethyl radical 43. However, if a cyclopropylmethyl radical $\mathbf{4 3}$ is involved as an intermediate two competing manners of stabilization (ring opening and B-elimination) could occur. Since the B-elimination of phenylthio radical in the acyclic systems is a fast reaction $\left(\mathrm{K}_{\mathrm{e}} \geq 1.6 \times 10^{7} \mathrm{sec}^{-1}\right)$ even at room temperature we estimate that at toluene boiling point $\left(111^{\circ} \mathrm{C}\right)$ it could be higher than the cyclopropane ring opening $\left(\mathrm{K}_{\mathrm{f}}=1.3 \times 10^{8} \mathrm{sec}^{-1}\right)$ and in such a case 3-exo-cyclization could be a method of choice for the synthesis of vinylcyclopropane derivatives.

Elimination of phenylthio radical could also be a reversible reaction with its addition to the vinylcyclopropane $40,{ }^{18,28}$ but since its addition to the $\mathrm{C}=\mathrm{S}$ group of starting thiohydroxamic esters 39 is irreversible process this competing reaction has not considerable influence on the yields of vinylcyclopropane derivatives.

The yields of cyclopropane derivatives did not change whether secondary or tertiary 5-phenylthio-3-pentenyl radicals $\mathbf{4 2}$ were involved as intermediates, thus indicating that the intramolecular reaction leading to the cyclopropane ring does not depend on the nucleophilicity of the radical species. 
In addition to the free radical 3-exo-cyclizations, 2-vinylcyclopropane derivatives were obtained from the similar precursors, involving an intramolecular addition of 5-bromo-3-pentenyl type carbanion and a concerted elimination of a bromide anion. ${ }^{45}$

However, intramolecular addition of 5-phenylthio-3-pentenyl radical 42 (Scheme 13.), leading to the vinylcyclopropane derivatives $\mathbf{4 0}$, was completely suppressed when the reaction was performed in the presence of excess of radicophilic olefins, because the rate of intermolecular addition of 5-phenylthio-3-pentenyl radicals to these olefins was higher than the rate of 3-exo-cyclization. Therefore, in such a case the formation of 5-heptenyl type radicals 17 (Scheme 6.), by intermolecular addition to the radicophilic olefins and their subsequent cyclization to 2-vinylcyclopentane derivatives 13 took place.

\section{EXPERIMENTAL}

Solvents used in all of the experiments were distilled over calcium hydride. Purification and separation of the reaction products were carried out by column chromatography using silica gel 70-200 mesh (60 A). Analytical gas chromatography was performed on an Hewlett-Packard HP 1 or ULTRA 2 (25 m/0.2 mm capillary column). ${ }^{1} \mathrm{H}$-NMR spectra (ppm in $\delta$ values) were recorded in $\mathrm{CDCl}_{3}$ (if not otherwise stated) on an Varian FT 80-A (at $80 \mathrm{MHz}$ ); TMS was used as internal standard. IR spectra ( $\nu_{\max }$ in $\mathrm{cm}^{-1}$ ) were recorded on a Perkin-Elmer 457 grating instrument. Mass spectra were performed on Finnigan ITDS 700 and Hewlett-Packard HP 5790 instruments.

I. Decomposition of thiohydroxamic esters of 6-phenylthio-4-hexenoic acids 11 in the presence of radicophilic olefins.

I.A. Synthesis of 6-phenylthio-4-hexenoic acids 9. General procedure for the synthesis of 2-alkyl-6-phenylthio-4-hexenoic acids 9 involved alkylation of the corresponding esters 6 by $(E)$-1,4-dibromo-2-butene using lithium diisopropylamide as a base at $-78^{\circ} \mathrm{C}$ (Scheme 4.). ${ }^{46}$ By this method following methyl $\alpha$-alkylated 6-bromo-4-hexenoates 7 were prepared:

Methyl 2-benzyl-6-bromo-4-hexenoate 7a, b.p. $140{ }^{\circ} \mathrm{C} / 0.3 \mathrm{~mm} \mathrm{Hg},(60 \%) .{ }^{1} \mathrm{H}-\mathrm{NMR}(80 \mathrm{MHz}), \delta$ : 2.25-2.45 (m, 2H), 2.65-3.10 (m, 3H), 3.65 (s, 3H), 3.80-4.00 (m, 2H), 5.60-5.80 (m, 2H) and 7.00-7.40 $(\mathrm{m}, 5 \mathrm{H})$.

Methyl 2-methyl-2-benzyl-6-bromo-4-hexenoate $7 \mathrm{~b}$, oil, (85\%). ${ }^{1} \mathrm{H}-\mathrm{NMR}(80 \mathrm{MHz}), \delta: 1.00(\mathrm{~s}, 3 \mathrm{H})$, 2.15-2.45 (m, 2H), 2.60-3.10 (m, 2H), $3.65(\mathrm{~s}, 3 \mathrm{H}), 3.85-4.00(\mathrm{~m}, 2 \mathrm{H})$, 5.65-5.85 (m, 2H), 7.05-7.50 (m, $5 \mathrm{H})$.

Methyl 2-decyl-6-bromo-4-hexenoate 7c, oil purified over silica gel column, $(68 \%)$. ${ }^{1} \mathrm{H}-\mathrm{NMR}$ (80 $\mathrm{MHz}), \delta: 0.80(\mathrm{t}, 3 \mathrm{H}), 1.00-1.35$ (wide $\mathrm{s}, 18 \mathrm{H}), 2.05-2.50(\mathrm{~m}, 3 \mathrm{H}), 3.65(\mathrm{~s}, 3 \mathrm{H}), 3.80-3.95(\mathrm{~m}, 2 \mathrm{H}), 5.55-$ $-5.80(\mathrm{~m}, 2 \mathrm{H})$.

Methyl 2-cyclopentyl-6-bromo-4-hexenoate 7d, b.p. $130-135{ }^{\circ} \mathrm{C} / 2.2 \mathrm{~mm} \mathrm{Hg},(50 \%) .{ }^{1} \mathrm{H}-\mathrm{NMR}(80$ MHz), $\delta: 0.80-1.90(\mathrm{~m}, 9 \mathrm{H}), 2.15-2.35(\mathrm{~m}, 3 \mathrm{H}), 3.65(\mathrm{~s}, 3 \mathrm{H}), 3.80-4.00(\mathrm{~m}, 2 \mathrm{H}), 5.60-5.80(\mathrm{~m}, 2 \mathrm{H})$.

Methyl 1-(4-bromo-2-butenyl)-cyclopentanecarboxylate 7e, b.p. $120-122{ }^{\circ} \mathrm{C} / 1.2 \mathrm{~mm} \mathrm{Hg},(50 \%) .{ }^{1} \mathrm{H}$ -NMR (80 MHz), $\delta: 1.10-1.80(\mathrm{~m}, 6 \mathrm{H}), 1.80-2.20(\mathrm{~m}, 2 \mathrm{H}), 2.25-2.40(\mathrm{~m}, 2 \mathrm{H}), 3.65(\mathrm{~s}, 3 \mathrm{H}), 3.80-3.90(\mathrm{~m}$, $2 \mathrm{H})$, 5.55-5.75 (m, 2H). 
Methyl 1-(4-bromo-2-butenyl)-cyclohexanecarboxylate 7f, b.p. $100^{\circ} \mathrm{C} / 0.2 \mathrm{~mm} \mathrm{Hg}$, (56\%). ${ }^{1} \mathrm{H}-\mathrm{NMR}$ $(80 \mathrm{MHz}), \delta: 0.80-1.85(\mathrm{~m}, 8 \mathrm{H}), 1.85-2.15(\mathrm{~m}, 2 \mathrm{H}), 2.15-2.30(\mathrm{~m}, 2 \mathrm{H}), 3.65(\mathrm{~s}, 3 \mathrm{H}), 3.70-3.95(\mathrm{~m}, 2 \mathrm{H})$, 5.55-5.75 (m, 2H).

Bromo esters 7 were converted to the corresponding phenylthio esters 8 by treatment with equal amounts of sodium ethoxide and thiophenol, and thus following methyl esters of 6-phenylthio-4-hexenoic acids 8 were prepared (Scheme 4.):

Methyl 2-benzyl-6-phenylthio-4-hexenoate 8a, oil purified over silica gel column, (97\%). ${ }^{1} \mathrm{H}-\mathrm{NMR}$ (80 $\mathrm{MHz}), \delta: 2.10-2.35(\mathrm{~m}, 2 \mathrm{H}), 2.40-2.90(\mathrm{~m}, 3 \mathrm{H})), 3.35-3.60(\mathrm{~m}, 5 \mathrm{H}), 5.35-5.55(\mathrm{~m}, 2 \mathrm{H}), 6.90-7.30(\mathrm{~m}, 10 \mathrm{H})$.

Methyl 2-methyl-2-benzyl-6-phenylthio-hexenoate 8b, oil (91\%). ${ }^{1} \mathrm{H}-\mathrm{NMR}(80 \mathrm{MHz}), \delta: 1.00(\mathrm{~s}, 3 \mathrm{H})$, $2.20(\mathrm{~s}, 2 \mathrm{H}), 2.60-3.05(\mathrm{~m}, 2 \mathrm{H}), 3.45-3.60(\mathrm{~m}, 2 \mathrm{H}), 3.65(\mathrm{~s}, 3 \mathrm{H}), 5.45-5.65(\mathrm{~m}, 2 \mathrm{H}), 6.90-7.50(\mathrm{~m}, 10 \mathrm{H})$.

Methyl 2-decyl-6-phenylthio-4-hexenoate 8c, colorless oil (89\%). ${ }^{1} \mathrm{H}-\mathrm{NMR}(80 \mathrm{MHz}), \delta: 0.80(\mathrm{t}, 3 \mathrm{H})$, $1.10-1.40$ (wide s, $18 \mathrm{H}), 2.15-2.30(\mathrm{~m}, 3 \mathrm{H}), 3.40-3.55(\mathrm{~m}, 2 \mathrm{H}), 3.65(\mathrm{~s}, 3 \mathrm{H}), 5.40-5.60(\mathrm{~m}, 2 \mathrm{H}), 7.10-7.40$ (m, 5H).

Methyl 2-cyclopentyl-6-phenylthio-4-hexenoate 8d, yellow oil, (100\%). ${ }^{1} \mathrm{H}-\mathrm{NMR}(80 \mathrm{MHz}), \delta: 0.90$ $-2.00(\mathrm{~m}, 9 \mathrm{H}), 2.10-2.45(\mathrm{~m}, 3 \mathrm{H}), 3.40-3.55(\mathrm{~m}, 2 \mathrm{H}), 3.67(\mathrm{~s}, 3 \mathrm{H}), 5.40-5.65(\mathrm{~m}, 2 \mathrm{H}), 7.05-7.45(\mathrm{~m}, 5 \mathrm{H})$.

Methyl 1-(4-phenylthio-2-butenyl)-cyclopentanecarboxylate 8e, yellow oil, (99\%). ${ }^{1} \mathrm{H}-\mathrm{NMR}(80 \mathrm{MHz})$, $\delta: 0.80-2.00(\mathrm{~m}, 8 \mathrm{H}), 2.00-2.20(\mathrm{~m}, 2 \mathrm{H}), 3.30-3.50(\mathrm{~m}, 2 \mathrm{H}), 3.65(\mathrm{~s}, 3 \mathrm{H}), 5.30-5.50(\mathrm{~m}, 2 \mathrm{H}), 7.10-7.35(\mathrm{~m}$, $5 \mathrm{H})$.

Methyl 1-(4-phenylthio-2-butenyl)-cyclohexanecarboxylate 8f, oil (100\%). ${ }^{1} \mathrm{H}-\mathrm{NMR}(80 \mathrm{MHz}), \delta: 0.75$ $-1.60(\mathrm{~m}, 8 \mathrm{H}), 1.70-2.00(\mathrm{~m}, 2 \mathrm{H}), 2.05-2.20(\mathrm{~m}, 2 \mathrm{H}), 3.35-3.50(\mathrm{~m}, 2 \mathrm{H}), 3.55(\mathrm{~s}, 3 \mathrm{H}), 5.30-5.50(\mathrm{~m}, 2 \mathrm{H})$, 7.05-7.35 (m, 5H).

Hydrolysis of methyl 2-alkyl-6-phenylthio-4-hexenoate esters 8 were carried out by KOH and 18-crown-6-ether in benzene solution and following 2-alkyl-6-phenylthio-4-hexenoic acids 9 were prepared (Scheme 4.).

2-Benzyl-6-phenylthio-4-hexenoic acid 9a, (oil), (86\%). ${ }^{1} \mathrm{H}-\mathrm{NMR}(80 \mathrm{MHz}), \delta: 2.00-2.35(\mathrm{~m}, 2 \mathrm{H})$, 2.40-2.95 (m, 3H), 3.35-3.50 (m, 2H), 5.35-5.55 (m, 2H), 6.90-7.40 (m, 10H), $10.60(\mathrm{~s}, 1 \mathrm{H})$.

2-Methyl-2-benzyl-6-phenylthio-4-hexenoic acid 9b, yellow oil (95\%). ${ }^{1} \mathrm{H}-\mathrm{NMR}(80 \mathrm{MHz}), \delta: 1.00$ (s, $3 \mathrm{H}), 2.10-2.40(\mathrm{~m}, 2 \mathrm{H}), 2.60-3.00(\mathrm{~m}, 2 \mathrm{H}), 3.45-3.60(\mathrm{~m}, 2 \mathrm{H}), 5.45-5.65(\mathrm{~m}, 2 \mathrm{H}), 7.00-7.50(\mathrm{~m}, 10 \mathrm{H})$.

2-Decyl-6-phenylthio-4-hexenoic acid 9c, oil, (86\%). ${ }^{1} \mathrm{H}-\mathrm{NMR}(80 \mathrm{MHz}), \delta: 0.75$ (wide t, 3H), 1.00 -1.25 (wide s, $18 \mathrm{H}), 2.00-2.30(\mathrm{~m}, 3 \mathrm{H}), 3.30-3.45(\mathrm{~m}, 2 \mathrm{H}), 5.30-5.50(\mathrm{~m}, 2 \mathrm{H}), 7.00-7.20(\mathrm{~m}, 5 \mathrm{H})$.

2-Cyclopentyl-6-phenylthio-4-hexenoic acid 9d, colorless oil, (70\%). ${ }^{1} \mathrm{H}-\mathrm{NMR}$ (80MHz), $\delta: 1.00-1.90$ (m, 9H), 2.10-2.35 (m, 3H), 3.40-3.55 (m, 2H), 5.40-5.75 (m, 2H), 7.10-7.40 (m, 5H).

1-(4-Phenylthio-2-butenyl)-cyclopentanecarboxylic acid 9e yellow oil, (85\%). ${ }^{1} \mathrm{H}-\mathrm{NMR}(80 \mathrm{MHz}), \delta$ : $1.25-2.20(\mathrm{~m}, 8 \mathrm{H}), 2.25-2.35(\mathrm{~m}, 2 \mathrm{H}), 3.45-3.55(\mathrm{~m}, 2 \mathrm{H}), 5.45-5.60(\mathrm{~m}, 2 \mathrm{H}), 7.10-7.40(\mathrm{~m}, 5 \mathrm{H})$.

1-(4-Phenylthio-2-butenyl)-cyclohexanecarboxylic acid 9f, yellow oil, $(67 \%) .{ }^{1} \mathrm{H}-\mathrm{NMR}(80 \mathrm{MHz}) ; \delta$ : $1.00-2.10(\mathrm{~m}, 10 \mathrm{H}), 2.15-2.35(\mathrm{~m}, 2 \mathrm{H}), 3.45-3.60(\mathrm{~m}, 2 \mathrm{H}), 5.45-5.60(\mathrm{~m}, 2 \mathrm{H}), 7.10-7.40(\mathrm{~m}, 5 \mathrm{H})$.

I.B. Decomposition of thiohydroxamic esters of 2-alkyl-6-phenylthio-4-hexenoic acids 9 in the presence of radicophilic olefins. Method A. Thiohydroxamic esters 11 were prepared in situ without isolation. ${ }^{23,27}$ Acids 9 were converted to the corresponding acyl chlorides 10 by treatment with thionyl chloride in benzene solution. The excess of thionyl chloride and solvent were removed under reduced pressure. Acyl chloride ( $3 \mathrm{mM})$ dissolved in $3 \mathrm{ml}$ of benzene was added to the mixture containing $3.1 \mathrm{mM}$ of $\mathrm{N}$-hydroxypyridine-2-thione, 0.27 $\mathrm{g}(3.3 \mathrm{mM})$ of pyridine, $0.068 \mathrm{~g}(0.3 \mathrm{mM})$ of 4-dimethylaminopyridine (DMAP) and $7 \mathrm{ml}$ of benzene in an argon atmosphere and protected from light. The mixture was stirred $15 \mathrm{~min}$. at room temperature and under 
these experimental conditions thiohydroxamic esters 11a-f were prepared in almost quantitative yields (Scheme 4.).

To the prepared solution containing $3 \mathrm{mM}$ of thiohydroxamic esters $1112 \mathrm{mM}$ of electron deficient olefinic compound was added and the reaction mixture was irradiated by a $200 \mathrm{~W}$ tungsten lamp and during irradiation temperature of mixture raised to about $50^{\circ} \mathrm{C}$. The course of decomposition was monitored by TLC using benzene as an eluent). The decomposition was completed after $1 \mathrm{~h}$ irradiation of mixture. Benzene was then removed and mixture was purified by chromatography on silica gel column using benzene as an eluent. The reaction mixture was analyzed by GC and yields of reaction products (as a mixture of stereoisomers) were determined (Scheme 5.).

Method B. Decomposition of thiohydroxamic esters were also performed under thermal conditions. The toluene solution of esters of thiohydroxamic acid 11 was added during $5 \mathrm{~min}$ to the boiling toluene solution of 10 molar excess of electron deficient olefins and $10 \mathrm{mg}$ of AIBN. The mixture was refluxed for additional $15 \mathrm{~min}$ and starting ester, was completely decomposed (Scheme 5.).

Ethyl 2-vinyl-4-benzylcyclopentanecarboxylate 13a. Thiohydroxamic ester 11 was prepared starting from $0.842 \mathrm{~g}(2.7 \mathrm{mM})$ of 2-benzyl-6-phenylthio-4-hexenoic acid $9 \mathrm{a}$ and it was decomposed in the presence of 1 g (10 mM) of ethyl acrylate according to Method A. After purification by column chromatography ethyl 2-vinyl-4-benzylcyclopentane carboxylate was obtained as a colorless oil $(0.3 \mathrm{~g}, 43 \%)$. By GC analysis (using capillary column) mixture of two isomers was detected, in total yield of $71 \%$. IR (film): 3090, 3080, 3020, 2980, 2940,1730,1640,1605,1580,1495,1455,1375,1190,1160,1030,915, $750 \mathrm{~cm}^{-1}$. ${ }^{1} \mathrm{H}-\mathrm{NMR}(80$ MHz), $\delta: 1.25(\mathrm{t}, 3 \mathrm{H}), 1.35-2.50(\mathrm{~m}, 5 \mathrm{H}), 2.50-3.05(\mathrm{~m}, 4 \mathrm{H}), 4.10(\mathrm{q}, 2 \mathrm{H}), 4.80-5.15(\mathrm{~m}, 2 \mathrm{H}), 5.50-6.00$ $(\mathrm{m}, 1 \mathrm{H}), 7.00-7.50(\mathrm{~m}, 5 \mathrm{H})$. MS: $\left(\mathrm{M}^{+}\right) 258,214,185,168,91,65$.

4-Benzyl-2-vinylcyclopentanenitrile 13b. Thiohydroxamic esters $11 \mathrm{a}$ (prepared from $1 \mathrm{~g}, 3.2 \mathrm{mM}$ of 2-benzyl-6-phenylthio-4-hexenoic acid 9a) was decomposed in the presence of $1.59 \mathrm{~g}(30 \mathrm{mM})$ of acrylonitrile, in boiling toluene solution, according to Method B. By column chromatography (silica gel, using benzene as an eluent) it was isolated $0.22 \mathrm{~g}$ (33\%) of title compound as a colorless oil. By GC analysis (50\% yield) two isomers were detected in ratio $1: 1$. IR (film): $3080,3060,2920,2240,1640,1600,1495,1455,990,920$, $750,700 \mathrm{~cm}^{-1}$. ${ }^{1} \mathrm{H}-\mathrm{NMR}(80 \mathrm{MHz}), \delta: 0.80-2.50(\mathrm{~m}, 6 \mathrm{H}), 2.50-3.15(\mathrm{~m}, 3 \mathrm{H}), 5.00-5.30(\mathrm{~m}, 2 \mathrm{H}), 5.50-6.20$ (m, 1H), 7.00-7.40 (m, 5H). MS: $\left(\mathrm{M}^{+}\right), 211,184,170,143,120,91,77,65$.

3-Cyano-4-vinylbicyclopentane 13c. Thiohydroxamic ester $11 \mathrm{~d}$ (prepared from $0.7 \mathrm{~g}, 2.4 \mathrm{mM}$ of 2 -cyclopentyl-6-phenylthio-4-hexenoic acid 9d) was decomposed in the presence of $0.636 \mathrm{~g}(12 \mathrm{mM})$ of acrylonitrile according to Method A. 4-Cyclopentyl-2-vinylcyclopentanenitrile $13 \mathrm{c}$ was purified by column chromatography using petroleum ether/acetone $9: 1$. It was isolated $0.3 \mathrm{~g}$ (70\% and by GC $90 \%$ yield) of title compound as a colorless oil and by GC analysis a mixture of two isomers were detected in ratio of $1: 1$. IR (film): $3080,2950,2870,2240,1645,1450,950,920 \mathrm{~cm}^{-1} .{ }^{1} \mathrm{H}-\mathrm{NMR}(80 \mathrm{MHz}), \delta: 0.75-2.40$ (m, 14H), 2.45-3.10 (m, 2H), 4.95-5.30 (m, 2H), 5.50-6.25 (m, 1H).

3-Ethoxycarbonyl-4-vinylbicyclopentane 13d. Starting from $0.7 \mathrm{~g}(2.4 \mathrm{mM})$ of 2-cyclopentyl-6-phenylthio-4-hexenoic acid 9d the corresponding thiohydroxamic ester 11d was prepared and decomposed in the presence of $1.2 \mathrm{~g} \mathrm{(12} \mathrm{mM)} \mathrm{of} \mathrm{ethyl} \mathrm{acrylate} \mathrm{as} \mathrm{it} \mathrm{was} \mathrm{described} \mathrm{in} \mathrm{Method} \mathrm{A.} \mathrm{From} \mathrm{the} \mathrm{reaction} \mathrm{mixture}$ was isolated by chromatography on silica gel (petroleum ether/acetone $=9: 1) 0.28 \mathrm{~g} \mathrm{(50 \% ,} \mathrm{and} \mathrm{GC} \mathrm{yield}$ of $76 \%$ ) of the title compound. IR (film): $3080,2950,2860,1730,1640,1450,1375,1185,1160,920 \mathrm{~cm}^{-1}$. ${ }^{1} \mathrm{H}-\mathrm{NMR}(80 \mathrm{MHz}), \delta: 1.25(\mathrm{t}, 3 \mathrm{H}, J=6 \mathrm{~Hz}), 1.30-2.15(\mathrm{~m}, 14 \mathrm{H}), 2.25-3.00(\mathrm{~m}, 2 \mathrm{H}), 4.05(\mathrm{q}, 2 \mathrm{H}, J=$ $6 \mathrm{~Hz}), 4.75-5.10(\mathrm{~m}, 2 \mathrm{H}), 5.45-5.95(\mathrm{~m}, 1 \mathrm{H}) . \mathrm{MS}:\left(\mathrm{M}^{+}\right) 236$.

3-Methoxycarbonyl-3-methyl-4-vinylbicyclopentane 13e. 2-Cyclopentyl-6-phenylthio-4-hexenoicacid 9d $(0.56 \mathrm{~g}, 1.93 \mathrm{mM})$ was converted to the corresponding thiohydroxamic ester $11 \mathrm{~d}$ and allowed to react with 
$1.00 \mathrm{~g}(10 \mathrm{mM})$ of methyl methacrylate according to Method A. By chromatography on silica gel column (petroleum ether/acetone $=9: 1$ ) it was isolated $0.18 \mathrm{~g}$ (40\%, and GC yield of $64 \%$ ) of title compound. GC analysis shows presence of two isomers in ratio of $1: 1$. IR (film): 3080, 2950, 2870, 1730, 1640, 1450, 1380, 1000, $920 \mathrm{~cm}^{-1} .{ }^{1} \mathrm{H}-\mathrm{NMR}(80 \mathrm{MHz}), \delta: 1.05$ and $1.20(\mathrm{ss}, 3 \mathrm{H}), 1.25-2.40(\mathrm{~m}, 14 \mathrm{H}), 2.60-3.05(\mathrm{~m}$, $1 \mathrm{H}), 3.05$ and $3.15(\mathrm{ss}, 3 \mathrm{H}), 4.50-5.10(\mathrm{~m}, 2 \mathrm{H}), 5.45-6.00(\mathrm{~m}, 1 \mathrm{H})$. MS: $\left(\mathrm{M}^{+}\right) 236$.

4-Decyl-2-vinylcyclopentanenitrile 13f. 2-(4-Phenylthio-2-butenyl)-dodecanoic acid $9 \mathrm{c}(1.00 \mathrm{~g}, 2.76$ $\mathrm{mM}$ ) was converted to the corresponding thiohydroxamic ester $11 \mathrm{f}$ and it was decomposed in the presence of $0.636 \mathrm{~g} \mathrm{(12} \mathrm{mM)} \mathrm{of} \mathrm{acrylonitrile} \mathrm{(Method} \mathrm{A).} \mathrm{Title} \mathrm{compound} \mathrm{was} \mathrm{isolated} \mathrm{by} \mathrm{column} \mathrm{chromatography}(0.22$ $\mathrm{g}, 32 \%)$ as a colorless oil. By GC analysis of reaction mixture two isomers (1:1) were obtained in total yield of 63\%. IR (film): 3060, 2930, 2900, 2830, 2220, 1630, 1465, 1370, 1015, 980, $910 \mathrm{~cm}^{-1}$. ${ }^{1} \mathrm{H}-\mathrm{NMR}(80$ $\mathrm{MHz}$ ), $\delta: 0.85$ (wide s, $3 \mathrm{H}$ ), 1.25 (wide s) and 1.30-2.00 (m, 23H), 2.10-2.50 (m, 1H), 2.50-3.00 (m, $1 \mathrm{H}$ ), 4.95-5.30 (m, 2H), 5.50-6.00 (m, 1H).

3-Benzyl-5-vinyl-N-phenyl-1,2-cyclopentanedicarboximide 13g. Thiohydroxamicester 11g prepared from the 2-benzyl-6-phenylthio-4-hexenoic acid $9 \mathrm{a}(0.85 \mathrm{~g}, 2.7 \mathrm{mM})$ was reacted with $\mathrm{N}$-phenylmaleinimide $(0.69$ $\mathrm{g}, 4 \mathrm{mM})$ according to Method $\mathrm{A}$. Title compound was isolated $(0.35 \mathrm{~g}, 37 \%)$ as a white crystals, m.p. 146$-148{ }^{\circ} \mathrm{C}$ by chromatography on silica gel column using diisopropyl ether/petroleum ether $6: 4$ as an eluent. IR (KBr): 3070, 3020, 2950, 2910, 2840, 1700, 1640, 1600, 1495, 1450, 1390, 1200, 1160, 780, 765, 705, $700 \mathrm{~cm}^{-1} .{ }^{1} \mathrm{H}-\mathrm{NMR}(80 \mathrm{MHz}), \delta: 1.10-1.60(\mathrm{~m}, 2 \mathrm{H}), 1.75-2.10(\mathrm{~m}, 1 \mathrm{H}), 2.45-3.00(\mathrm{~m}, 3 \mathrm{H}), 3.30-3.40$ (m, $2 \mathrm{H})$, 4.95-5.25 (m, 2H), 5.85-6.30 (m, 1H), 7.20-7.50 (m, 10H).

4-Methyl-4-benzyl-2-vinylcyclopentanenitrile $13 \mathrm{~h}$. Thiohydroxamic ester $11 \mathrm{~h}$ prepared from the $0.3 \mathrm{~g}$ (0.92 $\mathrm{mM})$ of 2-methyl-2-benzyl-6-phenylthio-4-hexenoic acid 9b was allowed to react with $0.265 \mathrm{~g}(5 \mathrm{mM})$ of acrylonitrile by applying Method B. It was obtained, after chromatography on silica gel column (benzene), $0.08 \mathrm{~g} \mathrm{(40 \% ,} \mathrm{and} \mathrm{GC} \mathrm{yield} \mathrm{of} \mathrm{52 \% )} \mathrm{of} \mathrm{the} \mathrm{title} \mathrm{compound} \mathrm{as} \mathrm{a} \mathrm{colorless} \mathrm{oil.} \mathrm{IR} \mathrm{(film):} 2950,2930,2240$, $1640,1585,1200,1030,995,970,920,740,705 \mathrm{~cm}^{-1} .{ }^{1} \mathrm{H}-\mathrm{NMR}$ (80 MHz), $\delta: 1.00$ (s, 3H), 1.10-2.10 (m, $4 \mathrm{H}), 2.10-3.15(\mathrm{~m}, 4 \mathrm{H}), 4.90-5.30(\mathrm{~m}, 2 \mathrm{H}), 5.60-6.15(\mathrm{~m}, 1 \mathrm{H}), 6.90-7.40(\mathrm{~m}, 5 \mathrm{H})$.

Ethyl 3-vinyl-spiro/4.4Jnonane-2-carboxylate 13i. Starting from $1.0 \mathrm{~g}(3.62 \mathrm{mM})$ of 1-(4-phenylthio-2-butenyl)-cyclopentanecarboxylic acid $9 \mathrm{e}$ the corresponding thiohydroxamic ester $11 \mathrm{i}$ was prepared and reacted with $1.5 \mathrm{~g}(15 \mathrm{mM})$ of ethyl acrylate according to Method A. Title compound $13 \mathrm{i}$ was isolated by column chromatography (eluent: petroleum ether/acetone $9: 1$ ), as an oil, in $41 \%$ and GC yield of $80 \%(0.33 \mathrm{~g})$. GC analysis shows presence of two isomers in ratio of $1: 1.7$. IR (film): 3080, 2950, 2880, 2860, 1730, 1640, $1450,1380,1175,1160,920 \mathrm{~cm}^{-1} .{ }^{1} \mathrm{H}-\mathrm{NMR}(80 \mathrm{MHz}), \delta: 1.20(\mathrm{t}, 3 \mathrm{H}), 1.30-2.00(\mathrm{~m}, 12 \mathrm{H}), 2.10-3.10$ (m, $2 \mathrm{H}), 4.10(\mathrm{q}, 2 \mathrm{H}), 4.80-5.10(\mathrm{~m}, 2 \mathrm{H}), 5.50-6.00(\mathrm{~m}, 1 \mathrm{H}) . \mathrm{MS}:\left(\mathrm{M}^{+}\right) 222,193,176,149,119,93,79,41$.

2-Aceryl-3-vinyl-spiro[4.4Jnonane 13j. Thiohydroxamic ester of 1-(4-phenylthio-2-butenyl)cyclopentanecarboxylic acid 11e was prepared as described in previous experiment and its decomposition was carried out in the presence of $0.27 \mathrm{~g} \mathrm{(15} \mathrm{mM)} \mathrm{of} \mathrm{methylvinyl} \mathrm{ketone} \mathrm{(Method} \mathrm{A).} \mathrm{Title} \mathrm{compound} \mathrm{was} \mathrm{isolated} \mathrm{by}$ distillation, b.p. $147-152{ }^{\circ} \mathrm{C} / 12 \mathrm{~mm} \mathrm{Hg}$ in yield of $37 \%$, GC yield $89 \%(0.27 \mathrm{~g})$. The ratio of two isomers of $7.7: 1$ was detected by GC analysis (total yield 89\%). IR (film): $3090,2950,2860,1740,1710,1450$, $1360,1170,1000,915 \mathrm{~cm}^{-1} .{ }^{1} \mathrm{H}-\mathrm{NMR}(80 \mathrm{MHz}), \delta: 1.25-1.90(\mathrm{~m}, 12 \mathrm{H}), 2.10(\mathrm{~s}, 3 \mathrm{H}), 2.55-3.00(\mathrm{~m}, 2 \mathrm{H})$, 4.80-5.10 (m, 2H), 5.50-6.00 (m, 1H). MS: $\left(\mathrm{M}^{+}\right) 192,149,122,93,43$.

2-Cyano-2-methyl-3-vinyl-spiro/4.5Jdecane 13k. 1-(4-Phenylthio-2-butenyl)-cyclohexanecarboxylic acid $9 \mathrm{f}(0.9 \mathrm{~g}, 3.1 \mathrm{mM})$ was converted to the corresponding thiohydroxamic ester $11 \mathrm{k}$ and decomposed in the presence of $1.0 \mathrm{~g}(15 \mathrm{mM})$ of methacrylonitrile according to Method A. By chromatography on silica gel column (benzene) it was isolated $0.3 \mathrm{~g}$ (50\%, GC yield $77 \%)$ of title compound as a pale yellow oil. Two isomers were obtained in ratio of $1: 2$. IR (film): $3080,2920,2860,2240,1640,1450,1380,1000,925 \mathrm{~cm}^{-1}$. 
${ }^{1} \mathrm{H}-\mathrm{NMR}(80 \mathrm{MHz}), \delta: 1.20(\mathrm{~s}, 3 \mathrm{H}), 1.25-2.35(\mathrm{~m}, 14 \mathrm{H}), 2.75-3.25(\mathrm{~m}, 1 \mathrm{H}), 4.95-5.30(\mathrm{~m}, 2 \mathrm{H}), 5.55-6.10$ (m, 1H). MS: $\left(\mathrm{M}^{+}\right) 203$.

2-Formyl-3-vinyl-spiro[4.5]decane 131. Thiohydroxamic ester 111 of 1-(4-phenylthio-2-butenyl)-cyclohexanecarboxylic acid $9 \mathrm{f}(0.77 \mathrm{~g}, 2.65 \mathrm{mM})$ was prepared as described in the previous experiment and it was decomposed in the presence of $0.84 \mathrm{~g}(15 \mathrm{mM})$ of acrolein, according to Method A. Title compound was isolated $(0.25 \mathrm{~g}, 58 \%, \mathrm{GC}$ yield $89 \%)$ as a colorless oil and consisting two isomers in ratio of $3: 1$. IR (film): $3080,2920,2860,1730,1640,1450,1000,920 \mathrm{~cm}^{-1} .{ }^{1} \mathrm{H}-\mathrm{NMR}(80 \mathrm{MHz}), \delta: 1.00-1.85$ (m, 14H), 2.10-3.05 (m, 2H)), 4.60-5.05 (m, 2H), 5.35-5.95 (m, 1H), 9.40 and 9,50 (d, 1H, $J=3 \mathrm{~Hz}): \mathrm{MS}:\left(\mathrm{M}^{+}\right)$ 192,163 (100\%), 149, 121, 107, 81, 67, 41 .

II. Decomposition of thiohydroxamic ester of 3-benzyl-6-phenylthio-4-hexynoic acid 24 in the presence of radicophilic olefins.

II.A. Synthesis of 2-benzyl-6-phenylthio-4-hexynoic acid 24. Synthesis of 2-benzyl-6-phenylthio-4-hexynoic acid was carried out by alkylation of methyl 3-phenylpropionate $(12 \mathrm{~g}, 73 \mathrm{mM})$ by 1,4-dibromobutyne $(17 \mathrm{~g}$, $80 \mathrm{mM}$ ) in the presence of $80 \mathrm{mM}$ of lithium diisopropylamide (from $7.74 \mathrm{~g}, 85 \mathrm{mM}$ of diisopropylamine and $53.2 \mathrm{ml}$ of 1.6 molar solution of butyl lithium in hexane, $85 \mathrm{mM}) .^{46}$ It was obtained $9.1 \mathrm{~g} \mathrm{(43 \% )}$ of methyl 2-benzyl-6-bromo-4-hexynoate, b.p. $168{ }^{\circ} \mathrm{C} / 0.3 \mathrm{~mm} \mathrm{Hg} .{ }^{1} \mathrm{H}-\mathrm{NMR}(80 \mathrm{MHz}), \delta: 2.40-2.60$ (m, 2H), 2.60-3.05 $(\mathrm{m}, 3 \mathrm{H}), 3.70(\mathrm{~s}, 3 \mathrm{H}), 3.95(\mathrm{t}, 2 \mathrm{H}, J=3 \mathrm{~Hz}), 7.05-7.25(\mathrm{~m}, 5 \mathrm{H})$.

2-Benzyl-6-phenylthio-4-hexynoic acid was obtained as a pale yellow oil, according to procedure described for the synthesis of corresponding olefinic acid (I.A.). ${ }^{1} \mathrm{H}-\mathrm{NMR}(80 \mathrm{MHz}), \delta: 2.20-2.45$ (m, $2 \mathrm{H}$ ), 2.60-3.00 (m, 3H), 3.50-3.60 (m, 2H), 7.00-7.35 (m, 10H), 11.00 (wide s, $1 \mathrm{H}$ ).

II.B. Decomposition of thiohydroxamic ester of 2-benzyl-6-phenylthio-4-hexynoic acid 24 in the presence of radicophilic olefins.

Thiohydroxamic ester 24 was prepared by reaction of 2-benzyl-6-phenylthio-4-hexynoic acid $(1.0 \mathrm{~g}$, $3.2 \mathrm{mM})$ with oxalyl chloride $(1.5 \mathrm{~g})$ and DMF $(0.1 \mathrm{~g})$ in benzene solution $(10 \mathrm{ml})$. Acyl chloride obtained in this experiment was converted to the thiohydroxamic ester by reaction with $0.41 \mathrm{~g}(3.2 \mathrm{mM})$ of N-hydroxypyridine-2-thione, $0.25 \mathrm{~g}(3.2 \mathrm{mM})$ of pyridine, and $0.06 \mathrm{~g}$ of DMAP, and it was decomposed in the presence $15 \mathrm{mM}$ of radicophilic olefins.

4-Benzyl-2-vinylidenecyclopentanenitrile 25a. Thiohydroxamicesterof2-benzyl-6-phenylthio-4-hexynoic acid 24, prepared as it was described above, and decomposed in the presence of $0.8 \mathrm{~g}(15 \mathrm{mM})$ of acrylonitrile, according to Method A. 4-Benzyl-2-ethenylidenecyclopentanenitrile 25a was isolated as a colorless oil $(0.21 \mathrm{~g}, 32 \%, \mathrm{GC}$ yield $61 \%)$ by chromatography on silica gel column (benzene). Two isomers were detected by GC analysis. IR (film): 3090, 3070, 3030, 2930, 2250, 1970, 1610, 1580, 1500, 1450, 860, $745 \mathrm{~cm}^{-1} .{ }^{1} \mathrm{H}-\mathrm{NMR}(80 \mathrm{MHz}), \delta: 1.40-2.50(\mathrm{~m}, 5 \mathrm{H}), 2.50-2.70(\mathrm{~m}, 2 \mathrm{H}), 3.25-3.70(\mathrm{~m}, 1 \mathrm{H}), 4.75-5.00(\mathrm{~m}$, $2 \mathrm{H}), 6.90-7.50(\mathrm{~m}, 5 \mathrm{H})$. MS: $\left(\mathrm{M}^{+}\right) 209,182,167,118,117,92,91(100 \%), 65$.

Ethyl 4-benzyl-2-vinylidenecyclopentanecarboxylate 25b. Thiohydroxamic ester $24(3.2 \mathrm{mM})$ was decomposed in the presence of $1.5 \mathrm{~g}(15 \mathrm{mM}$ ) of ethyl acrylate (Method A) and title compound was obtained in $40 \%$ yield (isolated $0.33 \mathrm{~g}$, GC yield $65 \%$ ) as a colorless oil. By GC analysis two isomers were observed. IR (film): 3080, 3060, 3020, 2980, 2960, 2920, 1965, 1730, 1605, 1580, 1495, 1455, 1180, 1160, 1030, 855, $740,700 \mathrm{~cm}^{-1} .{ }^{1} \mathrm{H}-\mathrm{NMR}(80 \mathrm{MHz}), \delta: 1.25(\mathrm{t}, 3 \mathrm{H}, J=6 \mathrm{~Hz}), 1.40-3.10(\mathrm{~m}, 7 \mathrm{H}), 3.20-3.75(\mathrm{~m}, 1 \mathrm{H}), 4.15$ (q, $2 \mathrm{H}, J=6 \mathrm{~Hz}), 4.60-4.85(\mathrm{~m}, 2 \mathrm{H}), 6.90-7.60(\mathrm{~m}, 5 \mathrm{H})$. 
1-Methyl-4-benzyl-2-vinylidenecyclopentanenitrile 25c. By applying Method A thiohydroxamic ester of 2-benzyl-6-phenylthio-4-hexynoic acid $24(3.2 \mathrm{mM})$ was reacted with $1 \mathrm{~g}(15 \mathrm{mM})$ of methacrylonitrile and title compound was isolated $(0.27 \mathrm{~g})$ as an oil in yield of $41 \%, \mathrm{GC}$ yield $72 \%$. Two isomers were detected by GC analysis. IR (film): 3080, 3060, 3020, 2930, 2870, 2230, 1960, 1605, 1580, 1495, 1455, 860, 750, $705 \mathrm{~cm}^{-1} .{ }^{1} \mathrm{H}-\mathrm{NMR}(80 \mathrm{MHz}), \delta: 1.45$ and $1.50(\mathrm{ss}, 3 \mathrm{H}), 1.50-3.00(\mathrm{~m}, 7 \mathrm{H}), 4.75-5.00(\mathrm{~m}, 2 \mathrm{H}), 6.90-7.50$ (m, 5H). MS: $\left(\mathrm{M}^{+}\right) 223,181,155,141,132,131,117,115,105,104,92,91$ (100\%), 77, 65.

III. Decomposition of thiohydroxamic ester of 2-alkyl-6-phenylthio-4-hexenoic acid 39 in the absence of radicophilic olefins

2-Benzyl-1-vinylcyclopropane 40a. Thiohydroxamic ester 39a was prepared by conversion of $1.8 \mathrm{~g}(5.77$ $\mathrm{mM}$ ) of 2-benzyl-6-phenylthio-4-hexenoic acid 9a into the corresponding acyl chloride (by treatment with 0.71 $\mathrm{g}, 6 \mathrm{mM}$ of thionyl chloride) and then by reaction with $0.87 \mathrm{~g}(5.9 \mathrm{mM})$ of 3-hydroxy-4-methylthiazole-2(3H)thione, $0.474 \mathrm{~g}(6 \mathrm{mM})$ of pyridine and $0.06 \mathrm{~g}$ of DMAP. Thus prepared ester $39 \mathrm{a}$ was dissolved in $20 \mathrm{ml}$ of toluene and the solution was added slowly to the $50 \mathrm{ml}$ of boiling toluene. After the addition was completed the reaction mixture was refluxed for additional $30 \mathrm{~min}$. Toluene was removed by distillation and residue was purified by chromatography on silica gel column (benzene/ethyl acetate $98: 2$ ). It was isolated $0.29 \mathrm{~g} \mathrm{(32 \% \text {, }}$ GC yield 47\%) of title compound as a colorless oil. IR (film): 3060, 3030, 3000, 2920, 2860, 1640, 1605, $1585,1495,1480,1455,1440,1030,740,700 \mathrm{~cm}^{-1}$. ${ }^{1} \mathrm{H}-\mathrm{NMR}(80 \mathrm{MHz}), \delta: 0.55-0.75(\mathrm{~m}, 2 \mathrm{H}), 0.85-1.50$ (m, 2H), 2.65 (dd, $2 \mathrm{H}, J_{1}=8 \mathrm{~Hz}, J_{2}=4 \mathrm{~Hz}$ ), 4.75-5.15 (m, 2H), 5.25-5.70 (m, 1H), 7.25 (s, 5H). MS $\left(\mathrm{M}^{+}\right)$158, 143, 129, 115, 104, $91(100 \%), 79,65,51$.

1-Methyl-1-benzyl-2-vinylcyclopropane 40b. 4-Methyl-N-hydroxythiazole-2-thione ester of 2-methyl-2-benzyl-6-phenylthio-4-hexenoic acid 39b (prepared from $1.4 \mathrm{~g}, 4.3 \mathrm{mM}$ of acid and $0.63 \mathrm{~g}, 4.3 \mathrm{mM}$ of 4-methyl-N-hydroxythiazole-2-thione) was decomposed in boiling toluene $(50 \mathrm{ml})$ as it was described in previous experiment and it was isolated $0.185 \mathrm{~g}(25 \%$, GC yield $43 \%)$ 1-methyl-1-benzyl-2-vinylcyclopropane $40 \mathrm{~b}$ as a colorless oil. IR (film): $3080,3060,3020,2995,2905,1640,1605,1495,1455,1385,1085,1030,990$, $900,760,725,700 \mathrm{~cm}^{-1} .{ }^{1} \mathrm{H}-\mathrm{NMR}(80 \mathrm{MHz}), \delta: 0.35-0.90(\mathrm{~m}, 2 \mathrm{H}), 1.00(\mathrm{~s}, 3 \mathrm{H}), 1.10-1.65(\mathrm{~m}, 1 \mathrm{H}), 2.60$ and $2.65(\mathrm{ss}, 2 \mathrm{H}), 4.80-5.25(\mathrm{~m}, 2 \mathrm{H}), 5.35-6.00(\mathrm{~m}, 1 \mathrm{H}), 7.05-7.40(\mathrm{~m}, 5 \mathrm{H})$. MS: $\left(\mathrm{M}^{+}\right) 172,157,143$ (100\%), 129, 128, 91.

2-Decyl-1-vinylcyclopropane $40 \mathrm{c}$. Thiohydroxamic ester $39 \mathrm{c}$ was prepared from $3.0 \mathrm{~g}(8.3 \mathrm{mM})$ of 2-(4-phenylthio-2-butenyl)-dodecanoic acid and $1.28 \mathrm{~g}(8.7 \mathrm{mM})$ of 4-methyl-N-hydroxythiazole-2-thioneaccording to described procedure and decomposed in refluxing toluene $(50 \mathrm{ml})$. From the reaction mixture was isolated $0.5 \mathrm{~g}(30 \%, \mathrm{GC}$ yield $60 \%)$ of 2-decyl-1-vinylcyclopropane as an oil. By GC analysis was found that it is a mixture of two isomers with ratio of $1.75: 1$. IR (film): 3080, 3070, 3000, 2960, 1640, 1470, 1030, 990, 895 $\mathrm{cm}^{-1} .{ }^{1} \mathrm{H}-\mathrm{NMR}(80 \mathrm{MHz}), \delta: 0.10-0.65(\mathrm{~m}, 1 \mathrm{H}), 0.65-1.00(\mathrm{~m}, 4 \mathrm{H}), 1.05-1.50(\mathrm{~m}, 20 \mathrm{H}), 4.70-5.80(\mathrm{~m}, 3 \mathrm{H})$, MS: $\left(M^{+}\right) 208,180,166,152,138,124,110,108,96,82,81,79,69,67,54(100 \%), 43,41$.

\section{REFERENCES AND NOTES}

1. Čeković, Ž.; Saičić, R. Tetrahedron Letters, 1986, 27, 5893; Saicić, R; Čeković, Ž. Tetrahedron, 1990, 46, 3627.

2. Barton, D.H.R.; Zard, S.Z.;De Silva, E. J. Chem. Soc. Chem. Commun. 1988, 285.

3. Clive, D.L.J.; Angoh,A.G. J. Chem. Soc. Chem. Commun. 1985, 980. 
4. Curran, D.P. Radical Cyclization and Sequential Radical Reactions, In Comprehensive Organic Synthesis, vol. 4, Ch. 4.2 Ed. by B. M. Trost and I Fleming, Pcrgamon Press:Oxford. 1991; pp. 779831.

5. Ghosez, A.; Giese, B.; Zipse, H. C-Radikale in Methoden der organischen Chemie, Houben-Weil, Band E 19a/Teil 2, Ed. M. Regitz, M. and Giese,B; Georg Thieme Verlag, Stuttgart,1989; Giese, B. Radicals in Organic Synthesis: Formation of Carbon-Carbon Bonds. Ed. Baldwin, J.A. Pergamon Pres:Oxford.1986.

6. Curran, D.P. Synthesis, 1988, 417 (Part 1) i 489 (Part 2).

7. Tsang, R; Freser, B. Reid J. Am. Chem. Soc. 1986, 108, 2116.

8. Stork, G; Mook, R. Jr. J. Am. Chem. Soc. 1983, $105,3720$.

9. Curran, D.P.; Rakiewicz, D.M. J. Am. Chem. Soc. 1985, 107, 1448; Tetrahedron. 1985, 41, 3943.

10. Čeković, Ž; llijev, D. Tetrahedron Letters. 1988, 29, 1441.

11. Beckwith, A.L.J.; O'Shen, D.M.;Westwood, S.W. J. Am. Chem. Soc. 1988, 110, 2565.

12. Dowd, P; Choi, S.C. Tetrahedron. 1989, 45, 77.

13. Baldwin, J.A; Adlington, R.M; Robertson, J. Tetrahedron. 1989, 45, 909.

14. Stork, G; Sher, P.M. J. Am. Chem. Soc. 1983, 105, 6765.

15. Keck, G.E.; Burnett, D.A. J. Org. Chem. 1987, 52, 2958.

16. Curran, D.P: Adv. Free Radical Chemistry. 1990, 1, 121-157.

17. Curran, D.P.; Chen, M.-H. J. Am. Chem. Soc. 1987, 109, 6558.

18. Feldman, K.S.;Romanelli, A. L.; Ruckle, R.E.Jr.; Miller, R.F. J. Am. Chem. Soc. 1988, 110, 3300 .

19. Fleming, I. Frontier Orbitals and Organic Chemical Reactions, Wiley:Chichester.1976.

20. Giese, B, Angew. Chem. Internat. Edit. 1983, 22, 753.

21. Beckwith, A.L.J.; Ingold, K.U, Free Radical Rearrangements in Rearrangements in Ground $i$ Excited States, Ed by P. de Mayo, Vol. 1. Academic Press Inc: New York, 1980; Lusztyk, J.; Maillard, B.; Deycard, S; Lindsay,; Ingold, K.U. J. Org. Chem. 1987, 52, 3509.

22. Chatgilialoglu, C.; Ingold, K.U.; Scaiano, J.C, J. Am. Chem. Soc. 1981, 103, 7739.

23. Barton, D.H.R.; Crich, D.; Motherwell, W. B. Tetrahedron, 1985, 41, 3901; Crich, D. Aldrichimica Acta. 1987, 20, 35. Barton, D.H.R.; Crich, D.; Kretzschmar, G. J. Chem. Soc. Perkin Trans. I, 1986, 39.

24. Booth, T.E.; Green, J.L, Jr.; Shevlin, P.B. J. Am. Chem. Soc. 1976, 98, 951.

25. Newcomb, M.; Park, S.U. J. Am. Chem. Soc. 1986, $108,4132$.

26. Saicić, R.; Čeković, Ž. Tetrahedron Letters. 1990, 29, 4203.

27. Russell, G.A. Acc. Chem. Res, 1989, 22, 1; Russell, G.A.; Ngoviwatchoi, P.; Tachtoush, H.I.; Pla- Dalmau, A.; Khanna, R.K. J. Am. Chem. Soc. 1988, 110, 3530.

28. Miura, K.; Fugami, K.;Oshima, K.; Utimoto, K. Tetrahedron Letters. 1988, 29, 5135.

29. Curran, D.P.; van Elburg, P.H. Tetrahedron Lett. 1989, 30, 2501,; Curran, D.P.; Chen, M.-H.; Spletzer, E.; Seong, C.M.; Chang, C.-T. J. Am Chem. Soc. 1989, 111, 8872.

30. Beckwith, A.L.J.; Schiesser, C.H. Tetrahedron. 1985, 41, 3925.

31. Spellmeyer, D.C.; Houk, K.N. J. Org. Chem. 1987, 52, 959.

32. Prepared according to the synthetic Scheme 4., but instead of alkylation by (E)-1,4-dibromo-2butene alkylation of ester 6 was carried out by 1,4-dibromo-2-butyne. 
33. Effio, A.; Griller, D.; Ingold, K.U.; Beckwith , A.L.J.; Serelis, A.K. J. Am. Chem. Soc. 1980, $102,1734$.

34. Maillard, B.; Forrest, D.; Ingold, K.U. J. Am. Chem.. Soc. 1976, 98, 7024.

35. Halgren, T.A.; Howden, M.E.H.; Medof, M.E.; Roberts, I.D. J. Am. Chem. Soc. 1967, 89, 3051.

36. Clive, D.L.J.; Daigneault, S. J. Org. Chem. 1991, 56, 3803; Wilt, J. W. In Free Radicals, Vol. 1. Ed. By Kochi, J. K.; John Wiley: New York, Ch. 8. 1972; Surzur, J. M in Reactive Intermediates, Vol. 2. Ch. 3. Ed. by Abramovich, R, Plenum Pres: New York, 1982.

37. Montgomery, L.K.; Matt, J. W. J. Am. Chem. Soc. 1967, 89, 3050.

38. Dowd, P.; Choi, S.-Ch. J. Am. Chem. Soc. 1987, 109, 3493.

39. Stork, G.; Mook, R, Jr. Tetrahedron Letters. 1986, 27, 4529.

40. Giese, B.; Heinrich, N.; Horler, H.; Koch, W.; Schware, H. Chem. Ber. 1986, 119, 3528.

41. Bury, A.; Corker, S.T.; Johnson, M.D. J. Chem. Soc. Perkin Trans. I, 1982, 645.

42. Srikrishna, A.; Sharma, G. V.; Hemamalini, P, J. Chem. Soc. Chem. Commun. 1990, 1681.

43. Park, S. U.; Varick, T. R.; Newcomb, M. Tetrahedron Letters. 1990, 31, 2975.

44. Čeković, Ž.; Saičic, R. Tetrahedron Letters. 1990, 31, 6085.

45. Saičič, R. N.; Matović, R.; Čeković, Ž, Gazz. Chim. Ital. 1991, 121, 325.

46. Petragnani, N.; Yonashiro, M, Synthesis, 1982, 521. Petragnani, N.; Brocksom, T. J.; Ferraz, H. M. C.; Constantino, M. G, Synthesis. 1977, 112. 